\title{
Article \\ Analysis of Vertical Earth Pressure Acting on Box Culverts through Centrifuge Model Test
}

\author{
Inyeop Chu ${ }^{1}$, Sang-Kyun Woo ${ }^{1}$, Sang Inn Woo ${ }^{2}$, Joonyoung Kim ${ }^{3} \mathbb{D}$ and Kicheol Lee ${ }^{2, *(D)}$ \\ 1 Korea Electric Power Research Institute, 105 Munji-ro, Yuseong-gu, Daejeon 34056, Korea; \\ chu.inyeop@kepco.co.kr (I.C.); skwoo96@kepco.co.kr (S.-K.W.) \\ 2 Department of Civil and Environmental Engineering, Incheon National University, 119 Academy-ro, \\ Yeonsu-gu, Incheon 22012, Korea; siwoo@inu.ac.kr \\ 3 Division of Smart Interdisciplinary Engineering, Hannam University, 70 Hannam-ro, Daedeok-gu, \\ Daejeon 34430, Korea; jykim91@hnu.kr \\ * Correspondence: wlq4619@gmail.com; Tel.: +82-32-835-0775
}

check for updates

Citation: Chu, I.; Woo, S.-K.; Woo, S.I.; Kim, J.; Lee, K. Analysis of Vertical Earth Pressure Acting on Box Culverts through Centrifuge Model Test. Appl. Sci. 2022, 12, 81. https:// doi.org/10.3390/app12010081

Academic Editors: Yong Yuan and Muhammad Junaid Munir

Received: 23 November 2021 Accepted: 21 December 2021 Published: 22 December 2021

Publisher's Note: MDPI stays neutral with regard to jurisdictional claims in published maps and institutional affiliations.

Copyright: (C) 2021 by the authors. Licensee MDPI, Basel, Switzerland. This article is an open access article distributed under the terms and conditions of the Creative Commons Attribution (CC BY) license (https:// creativecommons.org/licenses/by/ $4.0 /)$.

\begin{abstract}
Due to the lack of surface space, most structures are heading underground. The box culvert is underground infrastructure and serves to protect the buried structure from the underground environments, but it has a different characteristic from other structures in that the inner space is empty. Therefore, in this study, the vertical earth pressure which is the most significant effective stress acting on a box culvert was measured by conducting a geotechnical centrifuge model test. A box culvert was installed following the embankment installation method, and the vertical earth pressure acting on it was measured considering the cover depth, gravitational acceleration, and loading and unloading conditions. The soil pressure measured was greater than the existing theoretical value under high cover depth and the unloading condition, which is considered as the variability of many soils or the residual stress acting under the loading condition. Finally, a goodness-of-fit test was conducted as a part of variability analysis. The measured earth pressure was found to be considerably larger than the existing theoretical value, and the variability was large as well. This means the existing theoretical equation is under-designed, which should be reflected in future designs.
\end{abstract}

Keywords: vertical earth pressure; box culvert; geotechnical centrifuge model test; variability analysis; goodness-of-fit test

\section{Introduction}

Infrastructure is a basic building block of social production or economic activity. It includes industrial infrastructure, such as dams, roads, ports, power plants, and telecommunication facilities, and social welfare and environmental infrastructure, such as schools, hospitals, and parks [1]. The global construction market in 2019 was estimated to be close to $\$ 500$ billion, and the construction market is essentially a large-scale infrastructure market [2]. Owing to the demand for replacing old infrastructure and constructing transportation infrastructure, construction worth tens of billions of dollars is underway or planned in Asia (Indonesia, Laos, China, and Middle East countries), as well as Europe, Canada, and Africa [3].

Recently, the use of "underground infrastructure" in urban underground spaces is increasing owing to the lack of surface space and the need for a better environment [4]. Representative underground infrastructure can be categorized as follows: (1) buried utilities such as water, electricity, gas, and telecommunications; (2) foundations of buildings and bridges; and (3) underground structures, such as tunnels, subways, buildings, and mines. Among these, there is a strong demand for the construction of buried utilities to provide various services to residents; moreover, the surface infrastructure installed on the ground and the relationship between surface structures and underground structures are important $[5,6]$. 
Therefore, to protect buried utilities from underground environments, such as groundwater and earth pressure, and surface loads, such as superstructure and traffic loads, box culverts are buried underground, and utilities are installed inside. Box culverts are mainly composed of materials of cast-in-place or precast reinforced concrete. The load applied to a box culvert is determined by the characteristics of the ground and the geometry and stiffness of the structure itself [7]. Currently, the vertical load acting on the upper section of a box culvert can be calculated theoretically as the sum of the ground surface load (superstructure or traffic load) and the earth pressure of the soil above the box culvert. However, the actual load may deviate from the theoretical value owing to the construction method involved (embankment or trench installation) and soil-box culvert interaction characteristics [8-13]. In addition, even if the same vertical load acts on the upper section of the box culvert, the resulting stress may differ depending on the position of the upper section because the inside of the box culvert is an empty space [14]. This stress is the vertical earth pressure acting on the upper section of the box culvert.

In this study, considering the increasing pace of urban underground space development, the vertical earth pressure acting on a box culvert used for electric power or gas transport is analyzed. The vertical earth pressure acting on box culverts has been investigated by various researchers with a focus on the characteristics of soil-structure interaction. Recently, scale model tests and numerical analysis were conducted according to the structural form (flat seam, round hinged, integral, and mortise) of the prefabricated reinforced concrete box culverts, stress-strain self-sensing precast-box culvert smart element design and experimental verification under loading conditions were analyzed [15,16]. In addition, studies on the effect of load and the use of box culverts in tunnels or railway tracks are being actively conducted [17-19]. These studies have mainly considered the width and height of the box culvert and the height of the backfill soil in numerical analyses, centrifuge tests, and field tests [19-26].

However, even the centrifuge model tests or field tests conducted in sophisticated and controlled environments are affected by the inherent uncertainty of soil and errors in the measurement process [27]. In addition, it is difficult to secure the reliability of numerical analyses, and the variation induced by the inherent uncertainty of soil and errors in the measurement process have not been considered in the latest research trends [28-31].

Therefore, in this study, the variability of vertical earth pressure acting on a box culvert is measured by conducting repetitive centrifuge model tests. For this purpose, a uniform sand ground was composed through sand pluviation using a funnel, and at the same time, a box culvert was installed as an embankment installation method. After the ground was composed, loading and unloading conditions were simulated through gravitational acceleration, and the test parameters were the height of backfill soil above the box culvert. Afterwards, the measured results were compared with the predicted results, and finally, a variability analysis was performed through a goodness-of-fit test.

\section{Vertical Earth Pressure Acting on Box Culverts}

The first solution for computing the vertical earth pressure acting on a box culvert was proposed by [8]. The vertical earth pressure acting on the top section of a box culvert is related to the relative movement between the central soil over the structure and the adjacent soil columns, and the vertical earth pressure acting on the bottom section of a culvert is the sum of the earth load on the top slab, frictional force on the sidewalls, and dead load of the structure. The vertical earth pressure acting on a box culvert largely depends on the type of construction (embankment or trench installation) because the relative settlement of the exterior soil prism and the central soil prism near the box culvert behaves differently depending on the type of construction. This relative settlement can be added to or removed from the weight of the central soil prism above the box culvert, and friction or shear stress between the exterior and the central soil prisms can be generated.

In embankment installation, the relative settlement of the exterior soil prism is larger than that of the central soil prism above the box culvert, as shown in Figure 1a. The arch- 
shaped deformation acts on the central soil prism, meaning that a negative arch is formed that increases the earth pressure on the substructure. Conversely, in trench installation, the relative settlement of the central soil prism is larger than that of the exterior soil prism, and deformation takes the form of an inverted arch, which is a positive arch. In this case, the direction of the friction or shear stress between the exterior and the central soil prisms is reversed, and the earth pressure is reduced by the corresponding stress, as shown in Figure $1 b$.

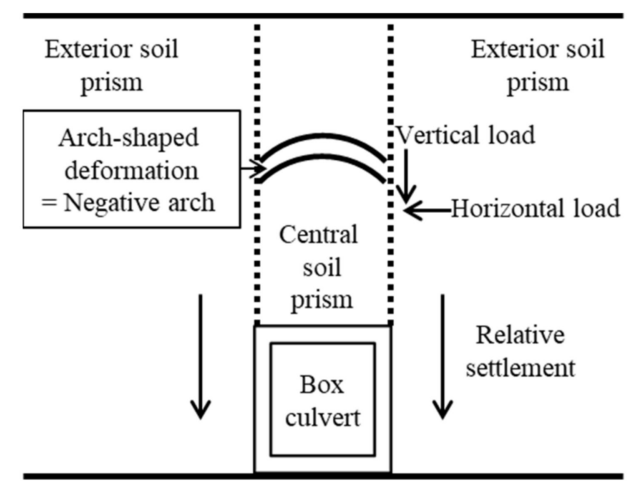

(a)

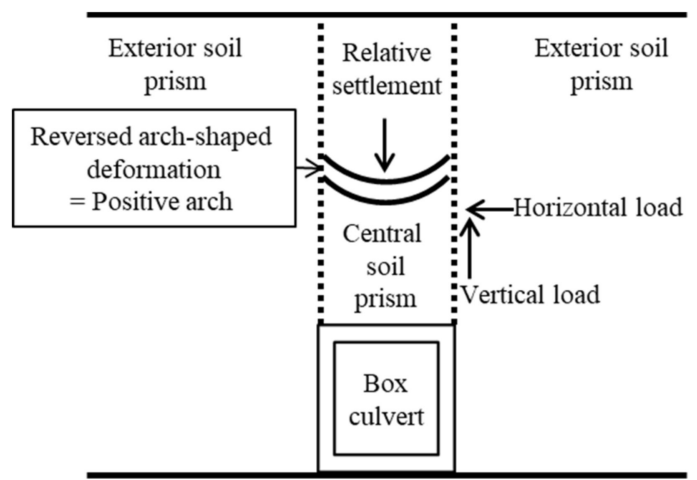

(b)

Figure 1. Soil behaviors with relative settlement: (a) embankment and (b) trench installation (modified after [32]).

\section{Centrifuge Model Tests}

In geotechnical engineering, centrifuge model tests are conducted primarily to reproduce the stress state of the actual ground by using a scale model specimen. The reducedscale model of the ground structure is rotated at high speed in the artificial acceleration field to simulate geotechnical problems, such as slope failure, changes in the bearing pressure of retaining walls, and soil-structure interactions [33-35]. The centrifugal force acting on the model as it is rotated in the centrifuge model test represents the gravitational acceleration $(N)$, and according to the magnitude of this gravitational acceleration, the scaling lows of the model, which are summarized in Table 1, can be applied [36].

Table 1. Scaling lows of centrifuge model tests [36].

\begin{tabular}{cccc}
\hline Factors & Symbols & Units & Scale Factors \\
\hline Length & $L$ & $L$ & $1 / N$ \\
Volume & $V$ & $L^{3}$ & $1 / N^{3}$ \\
Mass & $m$ & $m$ & $1 / N^{3}$ \\
Acceleration, Gravity & $a, g$ & $L / T^{2}$ & $N$ \\
Force & $F$ & $m L / T^{2}$ & $1 / N^{2}$ \\
Stress & $S$ & $m / L T^{2}$ & 1 \\
Modulus & $E$ & $m / L T^{2}$ & 1 \\
Strength & $S$ & $m / L T^{2}$ & 1 \\
Time, Dynamic & $t_{d y n}$ & $T$ & $1 / N$ \\
Length & $L$ & $L$ & $1 / N$ \\
\hline
\end{tabular}

\subsection{Device}

The specifications of the geotechnical centrifuge machine used in this study are shown in Figure 2 (Daewoo Institute of Construction Technology in Seoul, Korea). This geotechnical centrifuge has a rotation radius of $3.0 \mathrm{~m}$. The maximum test package size is $0.8 \mathrm{~m}$ in width, $1.0 \mathrm{~m}$ in diameter, and $0.8 \mathrm{~m}$ in height, and the payload capacity is $120 \mathrm{~g}$-ton. In addition, the slip ring for electrical signal interconnection between the inside and outside 
of the machine consists of four signal channels, four power channels for the power supply, and three video camera channels for real time observation.

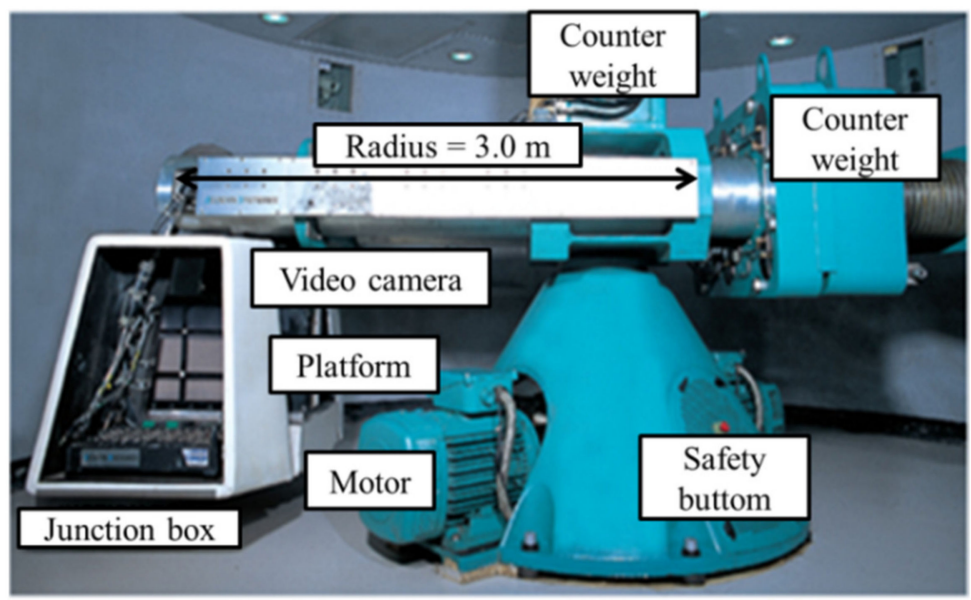

Figure 2. Geotechnical centrifuge (modified version of the machine in Daewoo Institute of Construction Technology in Seoul, Korea).

To perform the test, the specimen (in this study, the chamber containing soil and box culverts) is installed in the junction box for converting multiple single connectors and multi-connectors to each other in the geotechnical centrifuge, and the input and output voltages are measured. Thereafter, the data recorded by the data logger are transmitted through the optical communication slip ring.

\subsection{Box Culverts}

Figure 3 shows the scaled box culvert and the location of the earth pressure sensor inserted to conduct the centrifuge model test in this study. As shown in Figure 3a, the scaled box culvert was a rectangular box with a width of $5.2 \mathrm{~cm}$, height of $5.6 \mathrm{~cm}$, length of $20 \mathrm{~cm}$, and thickness of $0.15 \mathrm{~cm}$. When the gravitational acceleration reaches $50 \mathrm{~g}$, it corresponds to a box culvert with a width of $2.6 \mathrm{~m}$ and height of $2.8 \mathrm{~m}$ under the condition of $1 \mathrm{~g}$. Herein, we selected aluminum as the box culvert material to prevent bending deformation of the box culvert (a small box culvert made of concrete is highly likely to undergo deformation under gravitational acceleration).

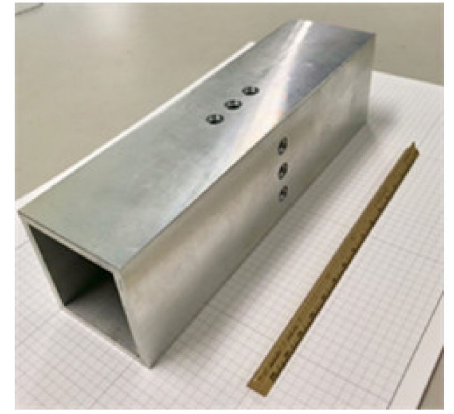

(a)
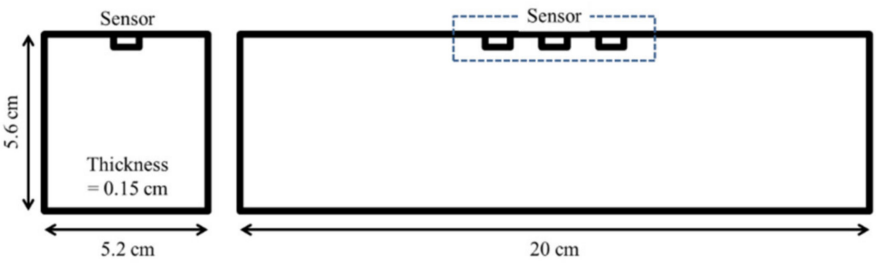

(b)

Figure 3. Specimens of scaled box culverts used in centrifuge model test: (a) specimen and (b) location of sensors for measuring vertical earth pressure.

An ultra-small strain-gauge-type earth pressure sensor was used in this study. As shown in Figure 3b, earth pressure was measured at three points along the lengthwise direction of the box culvert on the upper and lower surfaces. Both the input and output 
terminals were equipped with a four-phase power system, in which the positive and negative poles must be connected, which ensured stable measurement.

\subsection{Ground Composition}

\subsubsection{Material Properties of Soil}

Most of the centrifuge model tests that have been performed thus far have used poorly graded sand as the model ground to obtain stabilized results. However, the actual ground is mostly composed of granite weathered soil, which is classified as well-graded sand under the USCS (Unified Soil Classification System). Therefore, the model ground was constructed using well-graded sand. For this purpose, four types of poorly graded sands with specific particle sizes were mixed in a specific ratio. Table 2 shows the approximate particle size and mixing ratio of each poorly graded sand.

Table 2. Particle size and ratio of sand for well-graded sand.

\begin{tabular}{ccccc}
\hline Particle Size (mm) & $0.85-0.60$ & $0.60-0.25$ & $0.25-0.10$ & $0.10-0.075$ \\
\hline Ratio (\%) & 40 & 25 & 25 & 10 \\
\hline
\end{tabular}

A sieve test was conducted as prescribed in ASTM D2487 [37] to determine the particle size distribution of the mixed well-graded sand, and the results are shown in Figure 4a. The mixed sand has an even particle size distribution compared to that of the constituent poorly graded sands. The coefficient of uniformity $\left(C_{u}\right)$ and coefficient of curvature $\left(C_{c}\right)$ of the model soil as calculated from the particle size distribution curve are 4.09 and 1.18, respectively. These values do not correspond to the acceptance criteria prescribed in the USCS $\left(C_{u}>6\right.$, and $\left.1<C_{c}<3\right)$. However, the particle size of the mixed sand is close to that of well-graded sand than to that of poorly graded sand, which is the standard sand (e.g., Ottawa sand and Toyoura sand) used in existing centrifugal model tests.

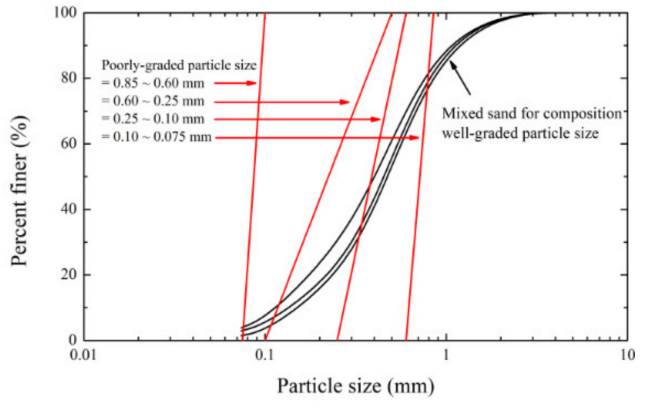

(a)

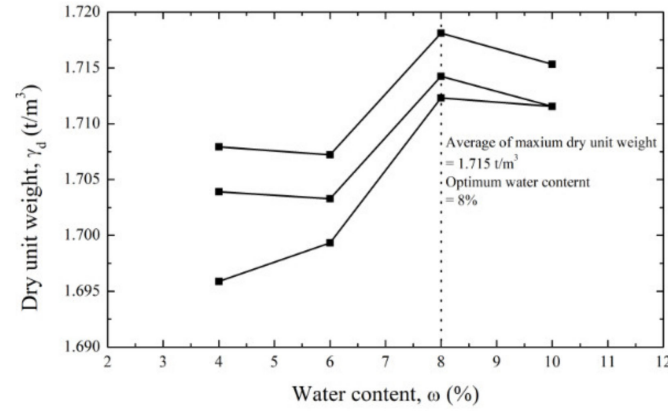

(b)

Figure 4. Results of laboratory test conducted using mixed well-graded sand: (a) particle size distribution obtained from sieve test and (b) compaction test to determine maximum dry unit weight and optimal water content of well-graded sand.

In addition, a laboratory compaction test was performed to determine the degree of compaction of the ground composed of well-graded sand according to ASTM D698 [38]. Figure $4 \mathrm{~b}$ shows the compaction curve obtained from the laboratory compaction test. According to this curve, the maximum dry unit weight of sand and its optimum water content were calculated as $1.715 \mathrm{t} / \mathrm{m}^{3}$ and $8 \%$, respectively.

\subsubsection{Sand Pluviation}

In this study, we targeted a degree of compaction of $95 \%$, and according to the compaction test results shown in Figure $4 \mathrm{~b}$, the model ground has a dry unit weight of $1.66 \mathrm{t} / \mathrm{m}^{3}$.

Traditionally, the model ground is created using the compaction method and pluviation methods that use a sieve or funnel. In the compaction method, a compaction plate 
is placed on the ground, and an impact is applied on top of it by using a rubber hammer. The compaction energy directly compact the ground. If the impact load applied during compaction is directly transmitted to the embedded sensors, the sensors may malfunction. To prevent this scenario, the ground should be compacted at a certain distance from the location where the sensor is installed; then, the gap between the ground and the sensors was filled with dried sand. However, in this case, it is highly likely that the ground will not be formed homogeneously, and the earth pressure condition may change owing to unexpected deformation of the ground.

In the pluviation method using a sieve, soil particles are allowed to fall freely after they pass through a sieve of a certain size. These soil particles are deposited on the chamber (or specimen) at a uniform speed, and the ground is formed with a homogeneous density. This is the most commonly used method for creating a model ground, and the density of the ground can be controlled by varying the drop height and sieve size. However, when the ground is created using well-graded soil, the possibility of material separation exists because the falling speed of soil composed of large particles is greater than that of soil with small particles. In other words, large particles may fall to the ground first, and therefore, it may not be possible to obtain a homogeneous ground composition.

Therefore, in this study, we adopted the funnel-based pluviation method, as shown in Figure 5a. Unlike the sieve-based pluviation method, in the funnel-based pluviation method soil is dropped through a steel pipe having a certain diameter rather than an open space, and the location of the ground composition is determined by the funnel location. The principle of this method is similar to that of the Tremi tube used for pouring concrete on cast-in-place piles. Because the sand falls through a steel pipe instead of an open space, the possibility of material separation is small, and the possibility of sensor breakage or malfunction is minimized.

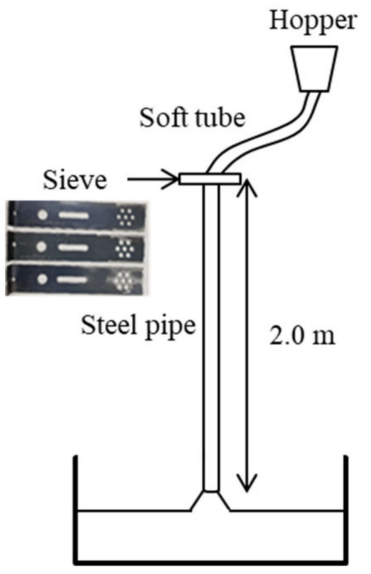

(a)
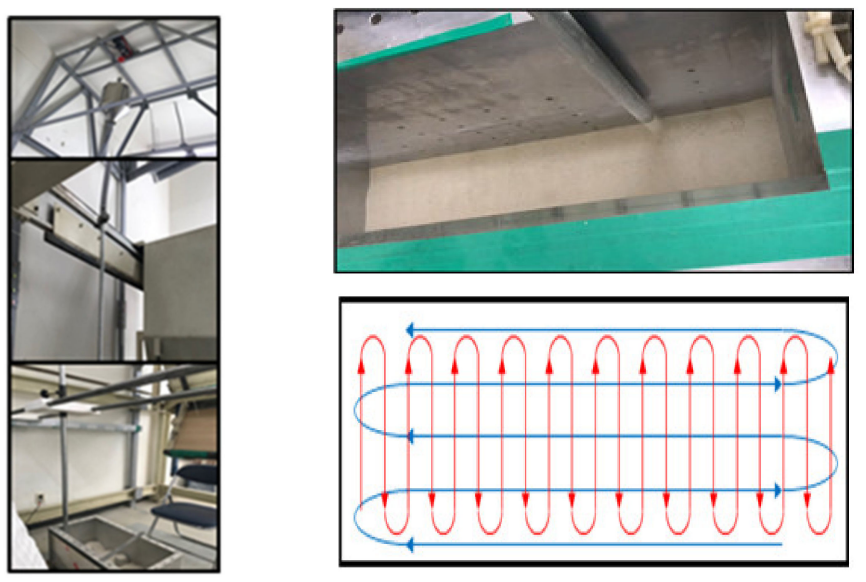

(b)

Figure 5. Sand pluviation using funnel: (a) equipment diagram and (b) composition method.

The model ground is created from left to right (blue solid line) and then vertically (red solid line), as shown in Figure $5 \mathrm{~b}$. Since density differences occur depending on the diameter of the sieve attached to the lower part of the soft pipe and the length of the steel pipe, the steel pipe length and sieve diameter corresponding to the target dry unit weight were selected based on the results of multiple tests (steel pipe length $=2.0 \mathrm{~m}$, sieve diameter $=4 \mathrm{~mm}$ ).

This method requires a skilled operator because density differences may occur depending on the operator's skill. Therefore, a process to verify the homogeneity of the ground is required, and to this end, we performed a small cone penetration test. As the homogeneity of the ground increases, the cone penetration resistance $\left(q_{c}\right)$ increases linearly with the penetration depth. By contrast, in the case of non-homogeneous ground, scattered data are obtained. Figure 6 shows the result of the cone penetration resistance test of the ground 
created using the funnel-based pluviation method; the results confirmed that homogeneous ground was created.

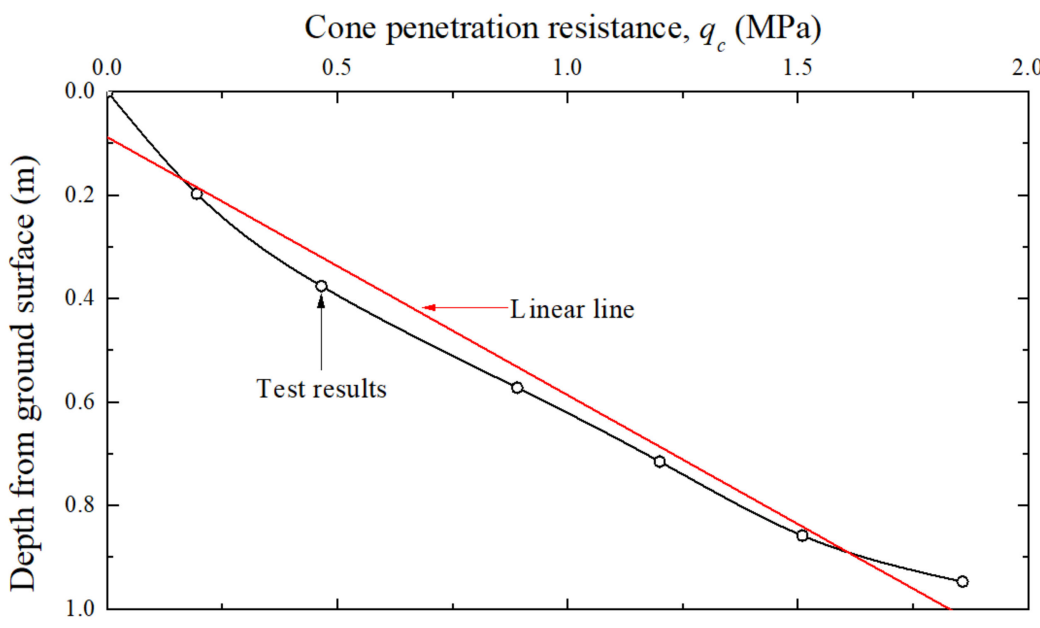

Figure 6. Conformity analysis of homogeneous ground through cone penetration test.

\subsection{Test Cases}

Figure 7 shows a schematic diagram of the box culvert installed in the ground for (a) the scaled model and (b) the actual model. In the scaled model ground, the depth of the soil layer under the box culvert was set to $20 \mathrm{~cm}$; the cover depth, that is, the thickness of the soil layer above the box culvert, was adjusted to 4, 8, and $12 \mathrm{~cm}$; and the earth pressure was measured on the top surface of the box culvert. The target gravitational acceleration of $50 \mathrm{~g}$ was applied, and the scaled model of the box culvert and ground conditions were converted into actual field conditions, as shown in Figure $7 \mathrm{~b}$.

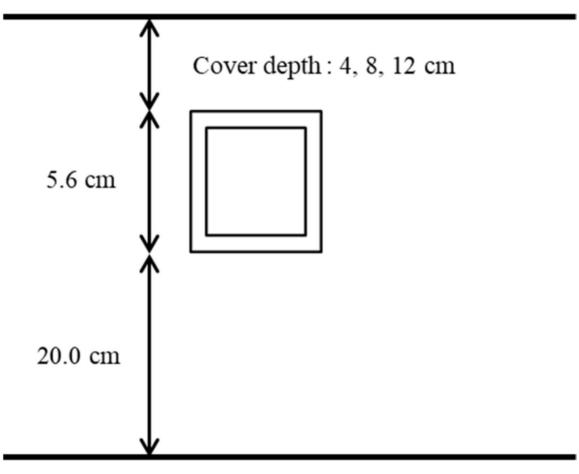

(a)

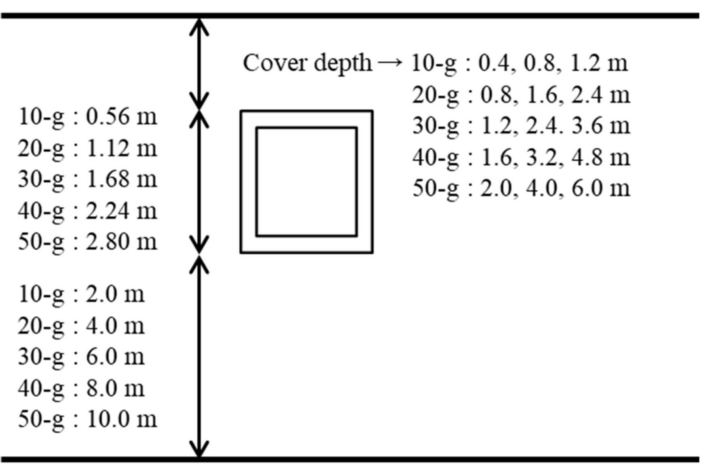

(b)

Figure 7. Diagram of box culvert: (a) scaled model in centrifuge model test and (b) actual model.

Figure 8 shows the process of applying gravitational acceleration to the box culvert in the centrifuge model test. After creating the model ground and installing the box culvert, in the ground stabilization stage, the gravitational acceleration applied to the model was increased in steps of $20 \mathrm{~g}$ to the final value of $100 \mathrm{~g}$. 


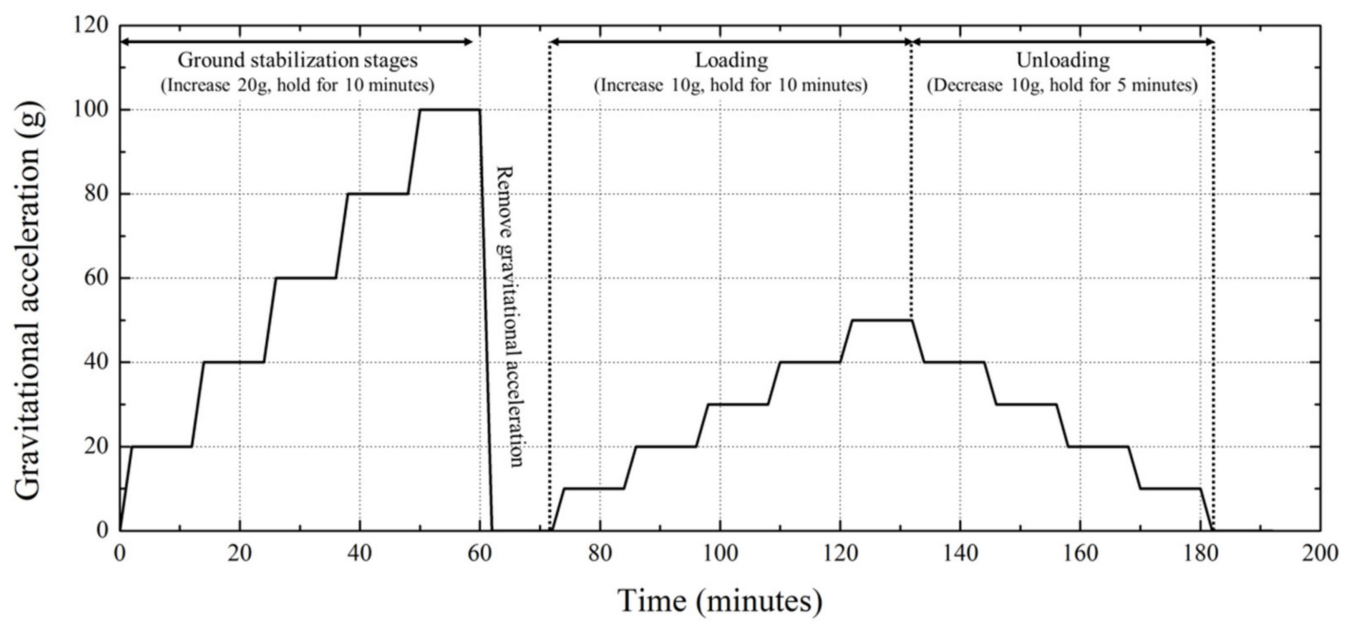

Figure 8. Process of applying gravitational acceleration.

The first objective of the ground stabilization phase is to measure and variability of the earth pressure in the normal consolidation state, and the second goal is to bring the ground into an overconsolidated state (when the previous load is greater than the current load). In general, because the top surface is compacted during the installation of the box culvert, the soil around the box culvert reaches an overconsolidated state. Therefore, in this study, $100 \mathrm{~g}$ of gravitational acceleration was first applied, and when the ground was sufficiently stabilized, the load was completely removed. Thereafter, in the loading stage, the gravitational acceleration was increased in steps of $10 \mathrm{~g}$ to the final target value of $50 \mathrm{~g}$. In each load, data were acquired for $10 \mathrm{~min}$ to adequately record the vertical earth pressure acting on the box culvert. In this case, $10 \mathrm{~g}, 20 \mathrm{~g}, 30 \mathrm{~g}, 40 \mathrm{~g}$, and $50 \mathrm{~g}$ correspond to the overconsolidation ratios of $10,5,3.33,2.5$, and 2.0, respectively.

Finally, in the unloading state, the gravitational acceleration was removed in steps of $10 \mathrm{~g}$, starting from $50 \mathrm{~g}$ and continuing until the target value of $1 \mathrm{~g}$ was reached. The earth pressure was measured by maintaining each state for $5 \mathrm{~min}$.

\section{Measurement Results of Vertical Earth Pressure Acting on Box Culvert}

\subsection{Theoretical Vertical Earth Pressure on Box Culvert}

The theoretical vertical earth pressure acting on the top of the box culvert in the centrifuge model test process can be calculated using Equation (1). Here, $\sigma_{v, \text { theo. }}$ is theoretical vertical earth pressure, $\gamma$ is the unit weight of sand when the degree of compaction is $95 \%$ $\left(1.66 \mathrm{t} / \mathrm{m}^{3}\right), h$ is the cover depth in the centrifuge model test $(4,8$, or $12 \mathrm{~cm})$, and $g$ denotes gravitational acceleration.

$$
\sigma_{v, t h e o}=\gamma \cdot h \cdot g
$$

\subsection{Measured Vertical Earth Pressure Acting on Box Culvert}

Figure 9 shows the vertical earth pressure measured in the centrifuge model test under the loading and unloading conditions. The centrifuge model test was performed twice with three sensors at each cover depth $(4,8,12 \mathrm{~cm})$, and a total of six data points were recorded at each gravitational acceleration (10, 20, 30, 40, and $50 \mathrm{~g})$.

The measured vertical earth pressure acting on the box culvert was greater in the unloading condition than in the loading condition. In addition, the loading condition exhibited a linear tendency with increasing gravitational acceleration. By contrast, the unloading condition exhibited a non-linear tendency with decreasing gravitational acceleration, as shown in Figure 9a-c. This is because the loading stage proceeded with the process of application of gravitational acceleration, unlike the unloading stage. That is, the vertical earth pressure of $50 \mathrm{~g}$ acted as the residual vertical earth pressure during the unloading process. 


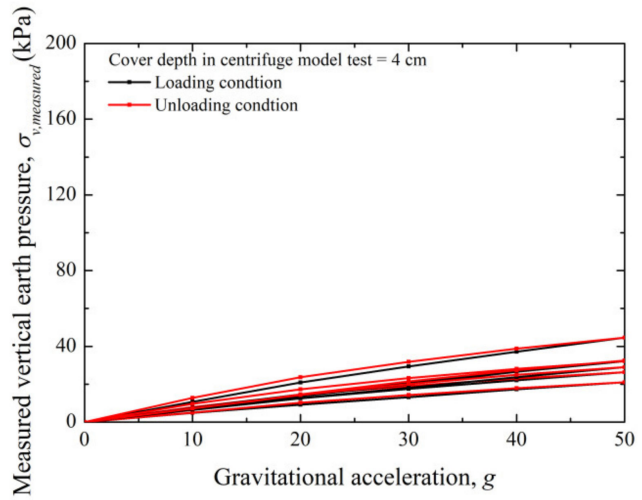

(a)

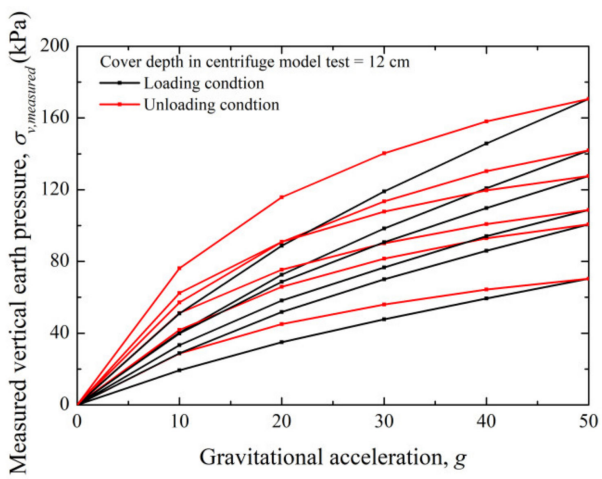

(c)

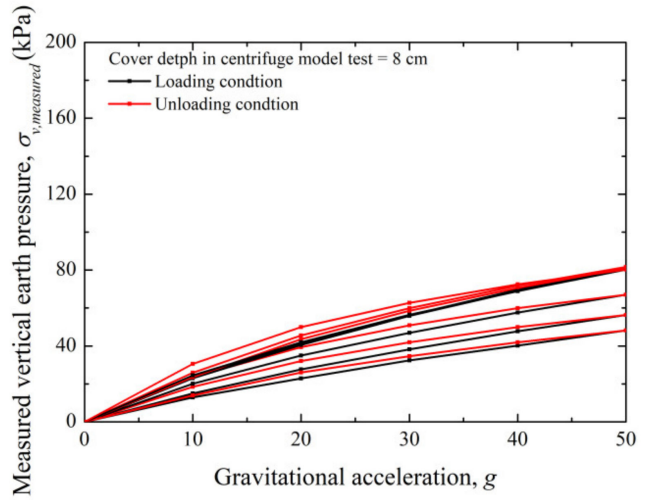

(b)

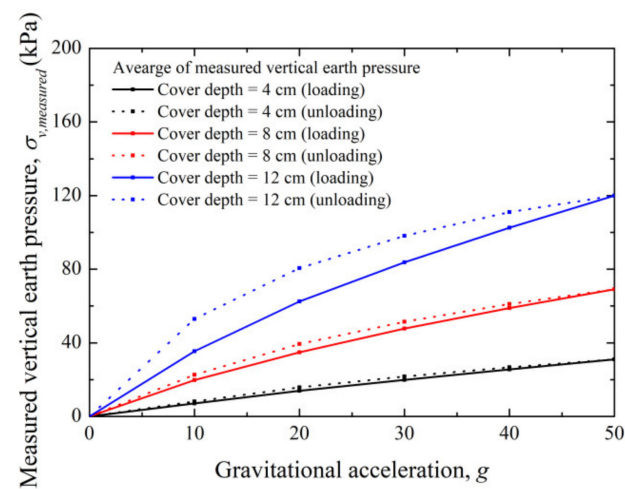

(d)

Figure 9. Measured vertical earth pressure under loading and unloading conditions; cover depth of (a) $4 \mathrm{~cm}$, (b) $8 \mathrm{~cm}$, (c) $12 \mathrm{~cm}$, and (d) average of measured vertical earth pressure.

For example, during the process of unloading from $50 \mathrm{~g}$ to $40 \mathrm{~g}$, the vertical earth pressure can be calculated as the sum of the vertical earth pressure of $40 \mathrm{~g}$ and the partial residual vertical earth pressure in the sensor at $50 \mathrm{~g}$. In the case of $30 \mathrm{~g}$, the residual vertical earth pressures of $50 \mathrm{~g}$ and $40 \mathrm{~g}$ are mixed non-linearly. With the progress of the unloading process, the residual vertical earth pressure gradually increases, and the difference between the data of the unloading and loading processes increases.

Figure $9 d$ shows the average measured vertical earth pressures (Figure 9a-c) for various cover depths. As the cover depths set during the ground formation process increased, the difference in vertical earth pressure increased. This result was ascribed to the fact that the influence of vertical earth pressure on the inherent variability of the ground increases with increasing cover depths. Because a large quantity of soil is loaded on the top of the box culvert, uncertainty, including inherent variability, increases, and it affects the residual vertical earth pressure.

\subsection{Relationship between Theoretical and Measured Vertical Earth Pressure}

Figure 10 shows a plot of the measured vertical earth pressure versus the theoretical vertical earth pressure under the loading and unloading conditions. Apart from the center line, where the theoretical and measured values are equal, most of the data are located in the upper right corner. This means that the theoretical values are under-designed or the measured values are higher than the actual values. 


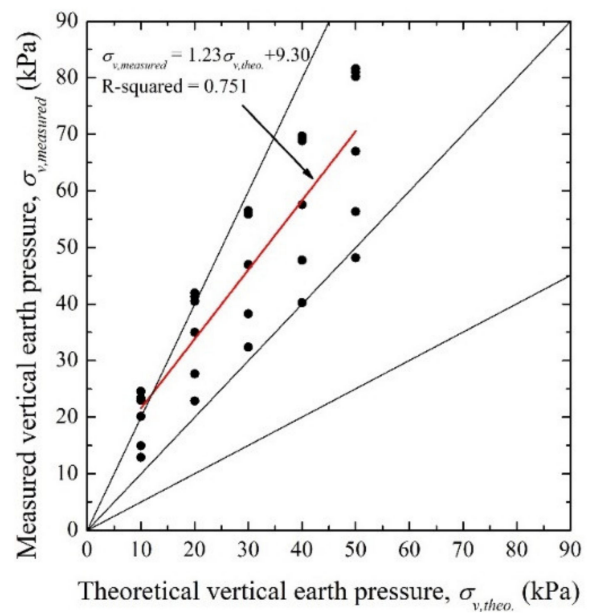

(a)

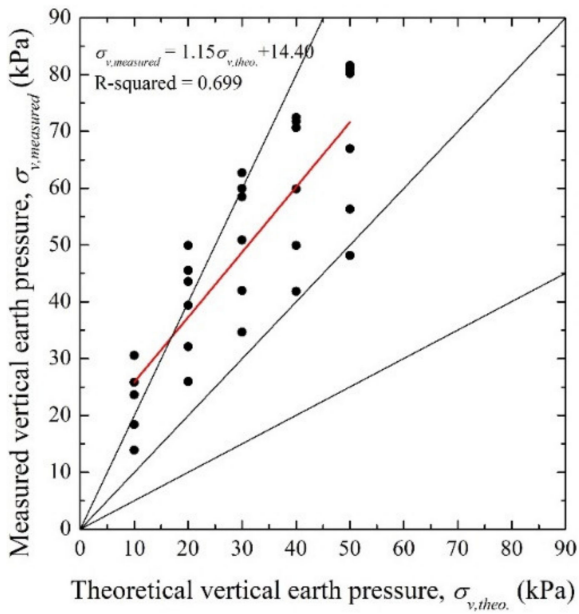

(b)

Figure 10. Theoretical vs. measured vertical earth pressure under the (a) loading and (b) unloading conditions.

Moreover, a linear regression analysis of the data indicated that the value of R-square in the loading condition was higher than that in the unloading condition. Here, R-square generally refers to the coefficient of determination, and its value ranges between 0 and 1 . If $\mathrm{R}$-square is 1 , all data are perfectly correlated. A low value of R-square indicates that the data measured from the established regression linear line are widely spread, which means that the variability is large.

\section{Variability Analysis of Vertical Earth Pressure Acting on Box Culvert}

\subsection{Estimation of Bias Factor}

The measured vertical earth pressure $\left(\sigma_{v \text {,measured. }}\right)$ shown in Figures 9 and 10 under the loading and unloading conditions and the theoretical vertical earth pressure $\left(\sigma_{v, \text { theo. }}\right)$ computed using Equation (1) were compared using Equation (2). The ratio $\lambda_{\sigma}$ represents the same concept as the bias factor (ratio of measured and nominal value) in load and resistance factor design (LRFD), and it can be used to judge the uncertainty of the measured vertical earth pressure and the appropriateness of the theoretical vertical earth pressure.

$$
\lambda_{\sigma}=\sigma_{v, \text { measured }} / \sigma_{v, \text { theo. }}
$$

When $\lambda_{\sigma}$ is close to 1.0 , the measured and theoretical values are similar, meaning that the test processes are accurate, and appropriate theoretical values are obtained. Under the assumption that the measured earth pressure is accurate, if $\lambda_{\sigma}$ is less than 1.0, the theoretical earth pressure is overestimated; if $\lambda_{\sigma}$ is greater than 1.0, it means that the theoretical earth pressure is underestimated. In this case, the theoretical earth pressure should be corrected appropriately. Similarly, under the assumption that the theoretical earth pressure is correct, if $\lambda_{\sigma}$ is less than 1.0, the measured vertical earth pressure is lower than the actual value; if $\lambda_{\sigma}$ is greater than 1.0, the measured vertical earth pressure is greater than the actual value. These scenarios may occur owing to the inherent variability of the ground or owing to measurement errors.

Figure 11 shows the bias factor calculated using Equation (2). Most of the bias factors exceed 1.0, and they tend to decrease as the gravitational acceleration increases. In addition, as the cover depth increases, the data scatter increases, and it is considered that an error is introduced in in the measurement process or an inappropriate theoretical value is computed owing to the uncertainty of the soil above the box culvert. 


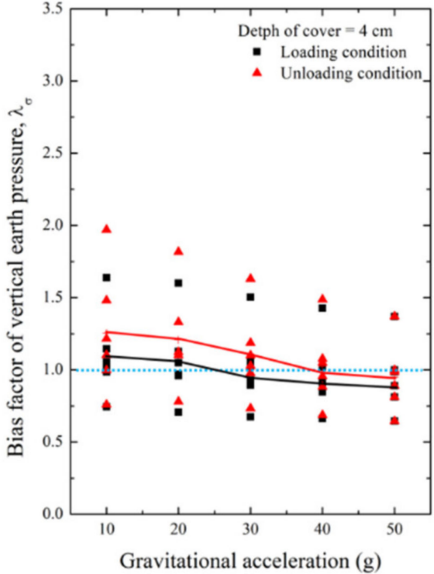

(a)

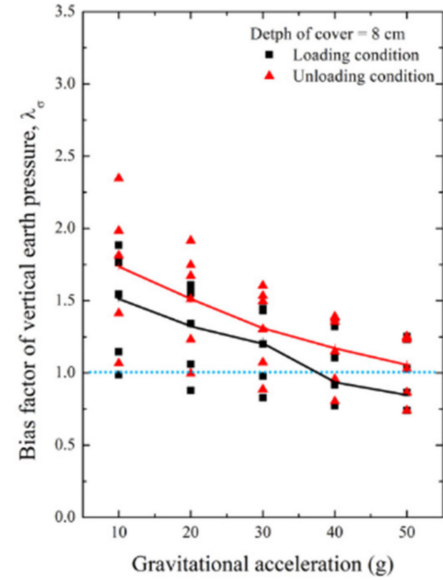

(b)

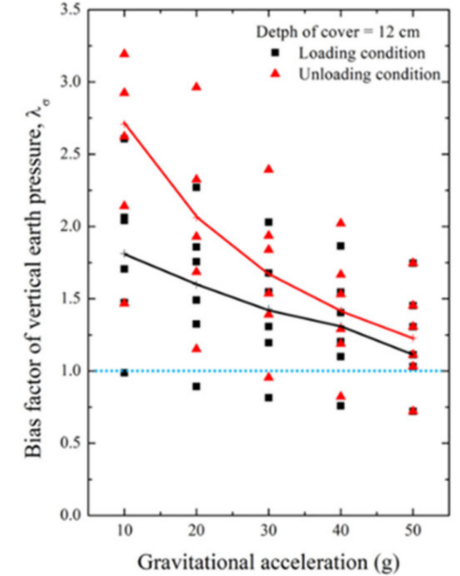

(c)

Figure 11. Bias factors of vertical earth pressure at cover depths of (a) $4 \mathrm{~cm},(\mathbf{b}) 8 \mathrm{~cm}$, and (c) $12 \mathrm{~cm}$.

\subsection{Calibration of Earth Pressure Sensors}

The centrifuge model test was conducted repeatedly in a strictly controlled environment. In the graph shown in Figure 11, the factors that can cause uncertainty include (1) inherent variability of soil such as unit weight and degree of compaction, and (2) measurement error.

In the case of the measurement error, the vertical earth pressure is generally measured using an earth pressure gauge, where the load is transmitted to the earth pressure sensor through the soil particles. However, if the load is not transmitted consistently to the earth pressure sensor, as shown in Figure 11, the measured earth pressure may not be accurate. In the cases of Sensors A and C, the earth pressure is underestimated, and in the case of Sensor $\mathrm{B}$, the earth pressure is overestimated. In addition, when the gravitational acceleration is set to $50 \mathrm{~g}$ during the centrifugal model test, the sensor size is important because the sensor diameter is enlarged by 50 times compared to that in the $1 \mathrm{~g}$ condition.

The best approach to overcome these inconsistencies in earth pressure measurement is to calibrate the sensor size, as shown in Figure 12. Miura et al. [39] proposed a sensor size for reliable earth pressure measurement based on the relationship between the sensor diameter $(d)$, and the maximum sample particle diameter $\left(D_{\max }\right)$. If " $d / D_{\max }>5$ ", the reliability of the error is $10 \%$ (at least two sensors); if " $d / D_{\max }>8$ ", the reliability of the error is $5 \%$ (at least five sensors). However, the sensor diameter (d) was $7.6 \mathrm{~mm}, D_{\max }$ was $2 \mathrm{~mm}$ in the centrifuge model test conducted in this study, and $d / D_{\max }$ was only 3.8. Therefore, the measured earth pressure contains a significant error, and error correction is required.

Therefore, for calibrating the sensor size, three data points measured in one test process were integrated. In other words, we assumed that Sensors A, B, and C in Figure 11a represent one integrated sensor as opposed to three different sensors, as shown in Figure $11 \mathrm{~b}$. The average of the vertical earth pressure values obtained using the three sensors was calculated, and this value was considered as the value measured using one sensor.

Here, the diameter of the integrated sensor $d_{\text {intergrated }}$, as calculated using Equation (3), is $13.16 \mathrm{~mm}$, and $d / D_{\max }$ is 6.58 . Therefore, based on the existing theory [40] the reliability of the error is $5-10 \%$. In addition, in the subsequent analysis, a total of 12 data points obtained under the loading and unloading conditions at a specific gravitational acceleration were integrated, and only four data points at a specific gravitational acceleration are shown. The data in Figure 11 were recalculated after sensor size correction, and the bias factor of vertical earth pressure for this correction is presented in Figure 13. Compared to the data in Figure 11, the spread range of the bias factor is reduced. 


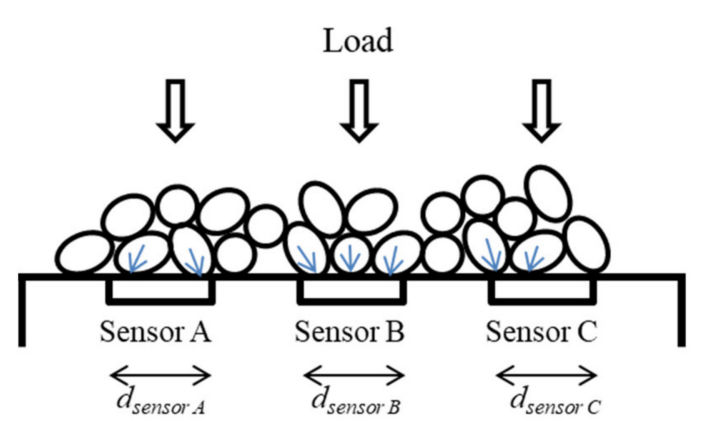

(a)

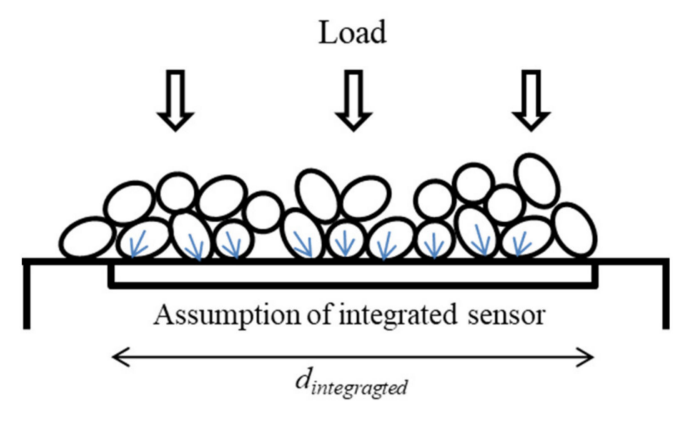

(b)

Figure 12. Example of earth pressure sensor with soil particle arrangement: (a) before and (b) after calibration.

$$
d_{\text {intergarted }}=\sqrt{\left[\left(d_{\text {sensor } A}\right)^{2}+\left(d_{\text {sensor B } B}\right)^{2}+\left(d_{\text {sensor } C}\right)^{2}\right]}=\sqrt{3 \times(7.6)^{2}}=13.16 \mathrm{~mm}
$$

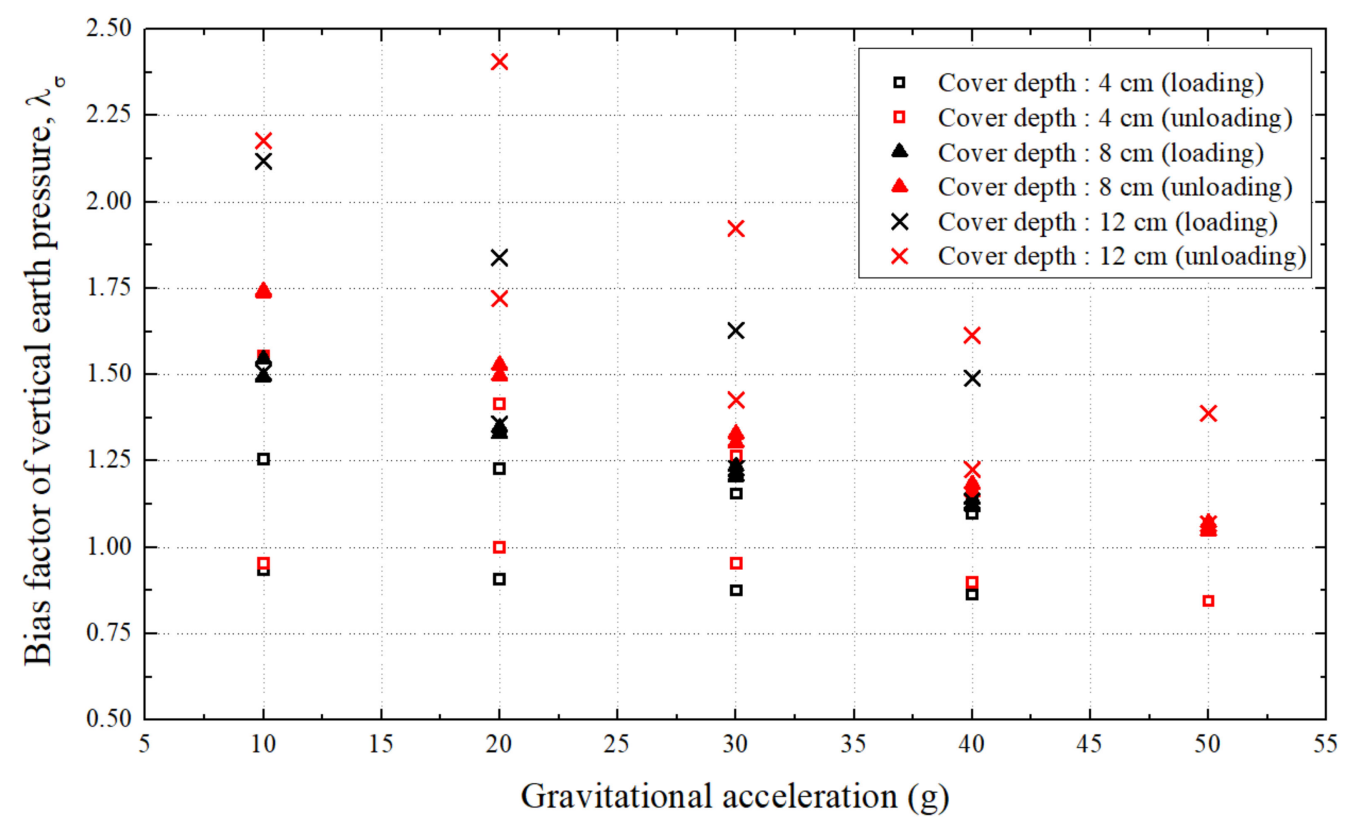

Figure 13. Recalculation of data after sensor size correction.

\subsection{Variability Analysis}

For variability analysis, the probability distribution function was analyzed under the loading and unloading conditions by conducting a goodness-of-fit test of the corresponding data. The goodness-of-fit test analyzes the difference between the values predicted using the given data and the probability distributions obtained by conducting the AndersonDarling (AD), Kolmogorov-Smirnov (KS), and chi-squared (CS) tests, and it determines the appropriate probability distribution [39]. The AD and KS tests can be applied even when the data sample is small, but the CS test can be applied only when the sample size is adequately large [41]. In this study, because the sample size was inadequate for the CS test, the goodness-of-fit was measured by conducting the AD and KS tests, and an appropriate probability distribution was obtained.

The goodness-of-fit test results are shown in Figure 14 and summarized in Tables 3 and 4 . The goodness-of-fit test analyzes the optimal probability distribution suitable for the histogram of the data in question, and a low value of the statistic indicates an optimal 
probability distribution. However, the analyzed fitted probability distribution is mainly used in other fields such as finance, accounting, and systems, and it represents a theoretical probability distribution that is difficult to implement in practice. For example, the "Burr" probability distribution is a log-logistic distribution that is mainly used in statistics and economics, "Johnson SB" is an asset model for financial portfolio management, "Dagun $(4 \mathrm{P})$ " is a personal income distribution model, and the "Gen.Extreme value" probability distribution is used for rainfall analysis. They have different directions for estimating uncertainty and variability in geotechnics.

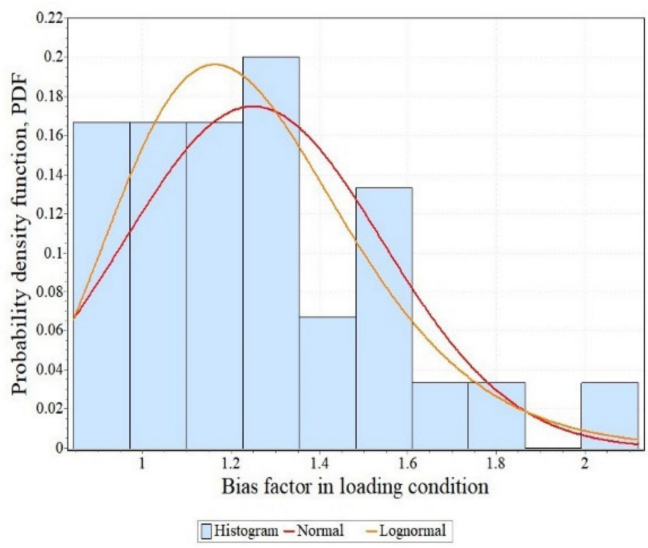

(a)

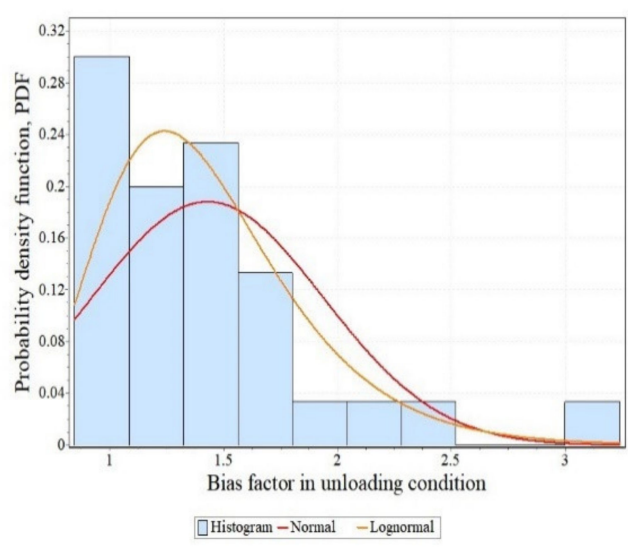

(b)

Figure 14. Probability density functions of normal and lognormal distribution under the (a) loading and (b) unloading conditions.

Table 3. Result of goodness-of-fit test under loading condition.

\begin{tabular}{cccccc}
\hline & KS Test & & \multicolumn{2}{c}{ AD Test } \\
\hline Rank & Probability Distribution & Statistic & Rank & Probability Distribution & Statistic \\
\hline 1 & Burr & 0.0709 & 1 & Burr & 0.1892 \\
\hline 2 & Log-logistic (3P) & 0.0731 & 2 & Gumbel Max & 0.1941 \\
\hline 3 & Pearson 6 & 0.0780 & 3 & Log-Pearson 3 & 0.1965 \\
\hline 4 & Pearson 5 & 0.0786 & 4 & Pearson 5 & 0.1966 \\
\hline 5 & Dagum & 0.0799 & 5 & Gen. Extreme value & 0.1989 \\
\hline 6 & Lognormal & 0.0809 & 13 & Lognormal & 0.2243 \\
\hline 41 & Normal & 0.1258 & 32 & Normal & 0.5341 \\
\hline
\end{tabular}

In the field of geotechnical engineering, sample data (physical properties, bearing capacity, etc.) are generally highly variable, unlike the data of standardized materials (such as concrete or metal). It is difficult to predict the population because the number of sample data are relatively small. Therefore, if an unusual probability distribution according to the goodness-of-fit test of the sample is applied in geotechnical engineering, uncertainty in the population estimation process may increase.

Generally, in geotechnical engineering, the normal and lognormal distributions are used. This is because the designer preemptively recognizes the uncertainty that occurs in the process of population estimation by selecting a probability distribution. This is partially reflected in the safety factor or resistance factor computed in the design process. Therefore, to select the optimal probability distribution in geotechnical engineering, it is reasonable to compare the normal and the lognormal distributions. Accordingly, in this 
study, we compared only the normal and lognormal distributions, and we considered the fitted probability distribution as lognormal.

Table 4. Result of goodness-of-fit test under unloading condition.

\begin{tabular}{cccccc}
\hline & KS Test & & \multicolumn{2}{c}{ AD Test } \\
\hline Rank & Probability Distribution & Statistic & Rank & Probability Distribution & Statistic \\
\hline 1 & Inv. Gaussian (3P) & 0.0629 & 1 & Log-Pearson 3 & 0.0928 \\
\hline 2 & Lognormal & 0.0651 & 2 & Gen. Extreme value & 0.1033 \\
\hline 3 & Fatigue Life (3P) & 0.0660 & 3 & Inv. Gaussian (3P) & 0.1038 \\
\hline 4 & Johnson SB & 0.0663 & 4 & Lognormal & 0.1039 \\
\hline 5 & Gen. Extreme value & 0.0671 & 5 & Fatigue Life (3P) & 0.1048 \\
\hline 6 & Log-Pearson 3 & 0.0685 & 6 & Pearson 5 & 0.1105 \\
\hline 32 & Normal & 0.1358 & 34 & Normal & 1.1953 \\
\hline
\end{tabular}

Table 5 presents the average, standard deviation, and coefficient of variation (COV) of the bias factor of vertical earth pressure under the loading and unloading conditions that follow the lognormal distribution. The COV is obtained by normalizing the standard deviation $\left(s_{x}\right)$ of a random variable against its mean $(\bar{x})$ by using Equation (4), and it indicates the variability of data. Herein, we considered only the loading and unloading conditions and did not confirm the effects of gravitational acceleration and cover depth owing to the lack of data.

Table 5. Variability analysis of the bias factor of vertical earth pressure under the loading and unloading conditions.

\begin{tabular}{ccc}
\hline Bias Factor & Loading & Unloading \\
\hline Average, $\bar{x}$ & 1.251 & 1.430 \\
\hline Standard deviation, $s_{x}$ & 0.286 & 0.499 \\
\hline COV & 0.228 & 0.349 \\
\hline Probability density function & Lognormal & Lognormal \\
\hline
\end{tabular}

The analysis of 30 data points measured under loading or unloading conditions revealed that the average and COV of the bias factor of vertical earth pressure were significantly measured under the unloading condition. That is, under the unloading condition, the measured vertical earth pressure due to residual stress was over-measured or a large stress was actually applied. In addition, the volatility was relatively large; therefore, in the actual design process, it is necessary to increase the factor of safety for allowable stress design (ASD) and decrease the resistance factor in load and resistance factor design (LRFD).

$$
\mathrm{COV}=\frac{s_{x}}{\bar{x}}
$$

\section{Discussion}

In this study, the variability and uncertainty of vertical earth pressure on a box culvert were evaluated through a geocentrifuge model test. The contents and results of the experiment and statistical analysis were shown in the main text, and the discussion is as follows.

i. The optimal probability distribution of variability of vertical earth pressure was determined according to the goodness-of-fit test. The lognormal distribution was selected as a result of considering both the KS and AS test results, because it is necessary to select a normal or lognormal distribution in terms of geotechnical uncertainty. Although 
the calculated COV cannot be said to be a small value, it is judged to be meaningful in that it is the selection of a predictive model for the corresponding result.

ii. As a result of the variability analysis, the vertical earth pressures under the loading and unloading state were measured to be 1.251 to 1.430 times greater than the existing theoretical earth pressure. This is considered an interaction problem between the top of the box culvert and the backfill soil, and AASHTO [42] defines it as a soilstructure interaction. In this case, the value of soil-structure interaction is used to conservatively compute the vertical earth pressure during the design process, and the value of soil-structure interaction is multiplied by the theoretical earth pressure. The soil-structure interaction should not exceed 1.15 for embankment installations and 1.40 for trench installations.

iii. In the centrifuge model test conducted in this study, embankment installation was adopted in the process of box culvert and ground formation. Therefore, the soilstructure interaction should not exceed 1.15 according to the existing AASHTO theory. However, the actual soil-structure interaction exceeded the prescribed value according to the loading and unloading conditions, and it exhibited considerable variability. This means that the previously set theoretical values do not reflect the actual environment, and it is necessary to check the variability of the actual ground during the design process.

iv. This study analyzed only the vertical earth pressure acting on the box culvert, and the effect on the horizontal earth pressure should be reviewed in the future. This is because it can calculate an important coefficient of earth pressure (K0) in the field of geotechnical engineering. Therefore, when horizontal earth pressure is analyzed in the same way, it is judged that detailed evaluation of earth pressure considering uncertainty is possible.

Author Contributions: Conceptualization, I.C., S.-K.W., S.I.W. and K.L. Methodology, I.C., S.-K.W. and J.K. Validation, I.C., S.-K.W., S.I.W., J.K. and K.L. Formal analysis, I.C., S.-K.W., J.K. and K.L. Investigation, I.C., S.-K.W., J.K. and K.L. Resources, I.C. and S.I.W. Data curation, S.I.W. and K.L. Writing-original draft preparation, I.C., S.-K.W., and K.L. Writing-review and editing, S.-K.W., S.I.W. and K.L. Visualization, S.-K.W., S.I.W., J.K. and K.L. Supervision, K.L. Project administration, I.C. and S.-K.W. Funding acquisition, S.-K.W., I.C., S.I.W. and K.L. All authors have read and agreed to the published version of the manuscript.

Funding: This research work has been supported by the Korea Electric Power Research Institute (Grant R18SA02), the Korea Institute of Energy Technology Evaluation and Planning (KETEP), the Ministry of Trade, Industry and Energy (MOTIE) of the Republic of Korea (No. 20194030202460) and the Korea Agency for Infrastructure Technology Advancement (KAIA) grant funded by the Ministry of Land, Infrastructure and Transport (Grant 21CTAP-C157021-02).

Institutional Review Board Statement: Not applicable.

Informed Consent Statement: Not applicable.

Data Availability Statement: Not applicable.

Acknowledgments: The authors acknowledge support by the Korea Electric Power Research Institute (Grant R18SA02), the Korea Institute of Energy Technology Evaluation and Planning (KETEP), the Ministry of Trade, Industry and Energy (MOTIE) (No. 20194030202460), and the Korea Agency for Infrastructure Technology Advancement (KAIA) under the Ministry of Land, Infrastructure, and Transport of the Korean government (Grant 21CTAP-C157021-02).

Conflicts of Interest: The authors declare no conflict of interest.

\section{References}

1. Lee, J.; Shin, S.; Lee, H.; Kim, D.; Lee, K. Analysis of the behavior characteristics of pile foundations responding to ground deformation. J. Korean Geosynth. Soc. 2020, 19, 21-32. (In Korean)

2. Kang, J. Overseas Construction Industry Trends in Semiannual of 2020; 2020 Semiannual Report; Export-Import Bank: Seoul, Korea, 2020; Volume 2020-02. (In Korean) 
3. Yoon, G. Global Trend of Infra Market; World \& Cites, Korea Trade-Investment Promotion Agency: Seoul, Korea, 2018; pp. 70-99. (In Korean)

4. Bobylev, N. Underground space as an urban indicator: Measuring use of subsurface. Tunn. Undergr. Space Technol. 2016, 55, 40-51. [CrossRef]

5. Hao, T.; Rogers, C.D.F.; Metje, N.; Chapman, D.N.; Muggleton, J.M.; Foo, K.Y.; Wang, P.; Pennock, S.R.; Atkins, P.R.; Swingler, S.G.; et al. Condition assessment of the buried utility service infrastructure. Tunn. Undergr. Space Technol. 2012, 28, 331-344. [CrossRef]

6. Rogers, C.D.F.; Hao, T.; Costello, S.B.; Burrow, M.P.N.; Parker, J.; Armitage, R.J.; Anspach, J.H.; Muggleton, J.M.; Foo, K.Y.; Wang, P.; et al. Condition assessment of the surface and buried infrastructure-a proposal for integration. Tunn. Undergr. Space Technol. 2012, 28, 202-211. [CrossRef]

7. Kim, K.; Yoo, C.H. Design loading on deeply buried box culverts. J. Geotech. Geoenviron. Eng. 2005, 131, 20-27. [CrossRef]

8. Marston, A.; Anderson, A.O. The Theory of Loads on Pipes in Ditches and Tests of Cement and Clay Drain Tile and Sewer Pipes; Bulletin 31; Iowa Engineering Experiment Station: Ames, IA, USA, 1913.

9. Marston, A. The Theory of External Loads on Closed Conduits in the Light of the Latest Experiments; Bulletin 96; Iowa Engineering Experiment Station: Ames, IA, USA, 1930.

10. Spangler, M.G. Field Measurements of the Settlement Ratios of Various Highway Culverts; Bulletin 171; Iowa Engineering Experiment Station: Ames, IA, USA, 1950.

11. Spangler, M.G. A theory on loads on negative projecting conduits. In Proceedings of the Highway Research Board, Washington, DC, USA, 9-12 January 1951.

12. Selig, E.T. Subsurface Soil-Structure Interaction: A Synopsis; Highway Research Record: Washington, DC, USA, 1972; pp. 1-4.

13. Vaslestad, J.; Johansen, T.H.; Holm, W. Load Reduction on Rigid Culverts beneath High Fills: Long-Term Behavior; Transportation Research Record: Washington, DC, USA, 1993; pp. 58-68.

14. Krishna, P.L.; Rajasekhar, D.K. Analysis and design of box culvert. Int. J. Sci. Technol. Eng. 2018, 4, 141-156.

15. Gong, Y.; Ma, Y.; Tan, G.; Bi, H.; Pang, Y.; Ma, C. Experimental Study and Numerical Simulation on Failure Process of Reinforced Concrete Box Culvert. Adv. Civ. Eng. 2020, 2020, 5423706. [CrossRef]

16. Gebremedhn, Z.; Qiao, G.; Sun, L.; Li, H.; Bai, S.; Jin, H. Strain/Stress Self-Sensing Precast-Box Culvert: Smart Element Design, and Experimental Verification. Int. J. Civ. Eng. 2021, 19, 851-859. [CrossRef]

17. Hussien, O.S. Reduction of box culvert stresses. Environ. Eng. Manag. J. 2020, 19, 1969-1974. [CrossRef]

18. Lu, X.; Liu, Y.; Zhang, L. Research on Deformation Characteristics of Tunnel Box Culvert Structure under Different Construction Loads. IOP Conf. Ser. Earth Environ. Sci. 2021, 634, 012136. [CrossRef]

19. Tarigan, J.; Nursyamsi, N.; Farhan, M. Precast box culvert analysis with direct load. IOP Conf. Ser. Mater. Sci. Eng. 2021, 1122, 012020. [CrossRef]

20. Woodbury, W.H.; Bayer, E.J.; Botts, A.E.; Daley, C.A.; Pettus, J.K.; Wilks, J.R. Corrugated metal culverts for railroad purposes Preparing specifications, with assistance of committee on iron and steel structures. Am. Railw. Eng. Assoc. 1926, 27, 794-828.

21. Braune, G.M.; Cain, W.; Janda, H.F. Earth pressure experiments on culvert pipe. Public Roads 1929, 10, $153-176$.

22. Spangler, M.G. Underground conduits-An appraisal of modern research. Trans. Am. Soc. Civ. Eng. 1948, 113, 316-345. [CrossRef]

23. Clarke, N.W.B. The loads imposed on conduits laid under embankments or valley fills. Proc. Inst. Civ. Eng. 1967, 36, 63-98.

24. Girdler, H.F. Loads on Culverts under High Embankments; Department of Transportation KYHPR-72-68: Lexington, KY, USA, 1974.

25. Dasgupta, A.; Sengupta, B. Large-scale model test on square box culvert backfilled with sand. J. Geotech. Eng. 1991, 117, 156-161. [CrossRef]

26. Yang, M.Z. Evaluation of Factors Affecting Earth Pressures on Buried Box Culverts. Ph.D. Thesis, University of Tennessee, Knoxville, TN, USA, 2000.

27. Bennett, R.M.; Wood, S.M.; Drumm, E.C.; Rainwater, N.R. Vertical loads on concrete box culverts under high embankments. J. Bridge Eng. 2005, 10, 643-649. [CrossRef]

28. Kulhawy, F.H. On the evaluation of static soil properties. In Stability and Performance of Slopes and Embankments II; ASCE: Reston, VA, USA, 1993; pp. 95-115.

29. Oshati, O.S.; Valsangkar, A.J.; Schriver, A.B. Earth pressures exerted on an induced trench cast-in-place double-cell rectangular box culvert. Can. Geotech. J. 2012, 49, 1267-1284. [CrossRef]

30. Chen, B.; Sun, L. Performance of a reinforced concrete box culvert installed in trapezoidal trenches. J. Bridge Eng. 2014, 19, 120-130. [CrossRef]

31. Zhang, J.H.; Yao, Y.S.; Zheng, J.L.; Zhang, T. Centrifugal model test and numerical simulation of vertical earth pressure on soft foundation box culvert. J. Cent. South Univ. 2015, 22, 3556-3563. [CrossRef]

32. Chen, B.; Meng, Q.; Yan, T.; Wang, C.; Song, D. New simplified method for analysis of earth pressure on the imperfect trench installation box culvert. Int. J. Geomech. 2020, 20, 04020193. [CrossRef]

33. Chen, B.G.; Zheng, J.J.; Han, J. Experimental study and numerical simulation on concrete box culverts in trenches. J. Perform. Constr. Facil. 2010, 24, 223-234. [CrossRef]

34. Schofield, A.N. Cambridge geotechnical centrifuge operations. Geotechnique 1980, 30, 227-268. [CrossRef]

35. Zhang, G.; Hu, Y.; Zhang, J.M. New image analysis-based displacement-measurement system for geotechnical centrifuge modeling tests. Measurement 2009, 42, 87-96. [CrossRef] 
36. Kutter, B.L. Dynamic Centrifuge Modeling of Geotechnical Structures; Transportation Research Record: Washington, DC, USA, 1992; pp. 24-30.

37. ASTM D2487. Standard Practice for Classification of Soils for Engineering Purposes (Unified Soil Classification System); American Society for Testing of Materials: West Conshohocken, PA, USA, 2017.

38. ASTM D698. Standard Test Methods for Laboratory Compaction Characteristics of Soil Using Standard Effort (12,400 ft-lbf/ft3 (600 $k N-m / m 3))$; American Society for Testing of Materials: West Conshohocken, PA, USA, 2017.

39. Miura, K.; Otsuka, N.; Kohama, E.; Supachawarote, C.; Hirabayashi, T. The size effects of earth pressure cells on measurement in granular materials. Soils Found. 2003, 43, 133-147. [CrossRef]

40. Alberto, M.O.; Carlos, G.F. Goodness-of-fit testing. Int. Encycl. Educ. 2010, 7, 190-196.

41. Jorge, L.R. Anderson-darling: A Goodness of fit test for small samples assumptions. Sel. Top. Assur. Relat. Technol. 2003, 10, 1-6.

42. AASHTO. LRFD Bridge Design Specifications, 9th ed.; American Association of State Highway and Transportation Officials: Washington, DC, USA, 2020. 